\title{
Development and Implementation of a Regional Program for the Safe Handling of Hazardous Drugs by Hospital Pharmacies
}

\author{
Barbara Sproll, Heather Milan, Cenzina Caligiuri, Sheri Dyck, Brenda Rosenthal, \\ and Colette $B$ Raymond
}

\section{INTRODUCTION}

$\mathrm{P}$ roviding a safe work environment is an important goal for any hospital pharmacy department. Historically, great care has been exercised in the receipt, storage, preparation, distribution, administration, and disposal of cytotoxic drugs. Although other drugs have been acknowledged as potentially hazardous, most facilities do not have processes to identify and ensure their safe and consistent handling. Existing medication and chemical safety programs have limitations in their applicability to hospital pharmacy practice. For example, the Workplace Hazardous Material Information System excludes prescription drugs. ${ }^{1}$ The US National Institute for Occupational Safety and Health $(\mathrm{NIOSH})$ recommends full handling precautions for all hazardous drugs. ${ }^{2}$ However, in a busy, diverse hospital pharmacy practice, application of such procedures may be impractical. The Canadian Society of Hospital Pharmacists (CSHP), in its "Hazardous Pharmaceuticals (Including Cytotoxic Drugs): Guidelines for Handling and Disposal", ${ }^{3}$ provides information about general issues related to handling hazardous products, but greater detail (for example, a list of specific drugs considered hazardous) was required to develop procedures for use by front-line staff.

The Winnipeg Regional Health Authority (WRHA) is a publicly funded organization that delivers acute, long-term, and community health services in Winnipeg, Manitoba (population catchment 800 000). The WRHA Pharmacy Program has a staff of approximately 150 full-time equivalent pharmacists and 150 full-time equivalent pharmacy technicians. Staff members of the WRHA Pharmacy Program deliver and manage pharmacy care at 8 facilities totalling about 2000 beds and provide selected pharmacy services for WRHA-affiliated clinics, personal care homes, and community health agencies. The WRHA has a single formulary for all acute care facilities.
This article describes the development and implementation of the Safe Handling of Hazardous Drugs Program within the WRHA Pharmacy Program. The purpose of this project was to develop practical guidelines for the safe handling of all potentially hazardous drugs. In 2007, the WRHA introduced a new policy for handling parenteral cytotoxic drugs, which was applicable to all regional staff. ${ }^{4}$ However, information was lacking about the safe handling of cytotoxic drugs administered by other routes and handling of potentially hazardous non-cytotoxic drugs; therefore, the WRHA Pharmacy Program struck a Hazardous Drugs Task Force. The regional Nursing Leadership Council was invited to participate in this task force, to help in developing safe handling processes for hazardous drugs that would also be applicable to nursing staff, but the Council chose not to participate; instead, they focused on implementation and education related to the new policy for cytotoxic drugs. Therefore, the task force worked on processes for the safe handling of hazardous drugs within the pharmacy, with the understanding that other health care disciplines would be included later, at a time of their choosing.

\section{PROJECT DESCRIPTION}

The development and implementation of the Safe Handling of Hazardous Drugs Program within the WRHA Pharmacy Program had the following objectives: to develop a list of drugs that might pose risks to those handling them; to develop procedures for receiving, storing, preparing, distributing, administering, and disposing of these drugs; to develop readily available tools for front-line pharmacy staff that could easily be amended for use by staff from other health care disciplines at a later date; and to develop a pharmacy implementation plan and training program. 
The WRHA Pharmacy Program began by convening the Hazardous Drugs Task Force, made up of pharmacy managers and staff from facilities within the WRHA and the provincial cancer agency, CancerCare Manitoba. Over the course of the project, other members were recruited for their expertise, as required (e.g., operations managers, educators). Other programs (e.g., nursing, Occupational and Environmental Safety and Health) were consulted for input specific to their respective areas of expertise.

\section{Develop List of Potentially Hazardous Drugs}

To identify drugs requiring safe handling practices, drug lists in the available guidelines from $\mathrm{NIOSH},{ }^{2} \mathrm{CSHP},{ }^{3}$ and the American Society of Health-System Pharmacists (ASHP) ${ }^{5}$ were reviewed. Through review of the literature, discussion, and consensus, definitions for cytotoxic drugs, non-cytotoxic hazardous drugs, and routine-handling drugs were determined for the Safe Handling of Hazardous Drugs Program. Cytotoxic drugs were defined as hazardous drugs that are detrimental or destructive to cells within the body. ${ }^{2}$ Cytotoxic agents generally bind to or damage DNA, interfere with DNA synthesis, or interfere with cell growth or proliferation. Often, cytotoxic drugs do not distinguish between normal and cancerous cells, disrupting growth or function of both types of cells. ${ }^{2.6}$ The term "cytotoxic" was used because health care workers in the WRHA understand this term and its relationship to the region's 2007 cytotoxic drugs policy. They also recognize the Canadian Standards Association (CSA) cytotoxic symbol that denotes drugs for which maximal handling precautions are required. ${ }^{3,4}$ Non-cytotoxic hazardous drugs were defined as drugs with less risk from occupational exposure relative to cytotoxic drugs, but for which special handling precautions are required. Routinehandling drugs were defined as drugs that do not require special safe-handling precautions.

The cytotoxic, non-cytotoxic hazardous, and routinehandling definitions were used to categorize all drugs in the WRHA formulary. In addition, drugs, powders, and chemicals used in compounding practices within the WRHA Pharmacy Program, as well as investigational drugs and drugs obtained through Health Canada's Special Access Programme, were categorized. Where clear information about categorization was not available (e.g., for investigational, foreign, or newly marketed drugs), the pharmacology, pharmaceutics, toxicology, and pharmacokinetics of the drug or compound and the categorization of similar drugs were considered. The procedures used to determine how a drug would be categorized are outlined in Table 1.

The drugs were tabulated to form the "Cytotoxic and Non-cytotoxic Hazardous Drugs" list (see Table 2 for an excerpt from this list). TALLman lettering, recommended by
Table 1. Criteria for Classifying Drugs ${ }^{2.5 *}$

Cytotoxic drugs
Mutagenic
Genotoxic
Carcinogenic
Non-cytotoxic, hazardous drugs
Reproductive effects
Teratogenic
Fetal developmental toxicity
Causing early fetal loss
Impairing fertility
Affecting uterine function
FDA pregnancy risk category X
Affecting endocrine function
Affecting immune system function
Transmission of infection
Respiratory irritants
Additional considerations for both classifications
Is the drug similar to other drugs already on our list?
Is the drug included on other organizations' hazardous
drug lists?
Does the drug cause serious organ toxicity at low doses?
Are there any relevant pharmacologic and/or pharmacokinetic
properties that may affect risk of exposure?
What is the level of evidence supporting the cytotoxic or
non-cytotoxic hazardous classification (randomized controlled
trial, case report, animal studies, etc.)?
*Drugs are classified as cytotoxic or non-cytotoxic hazardous if
there is evidence to support one or more of the criteria listed.
To ensure adequate protection, drugs that fit into both
categories are labelled "cytotoxic". Drugs that do not meet
any of the criteria may still be considered for addition to the
list on the basis of an individual hazard assessment.
theng

the US Institute for Safe Medication Practices (ISMP), was used in this table to help distinguish look-alike drug names. The use of TALLman letters has been promoted by ISMP, the Joint Commission, and other safety-conscious organizations as one means of reducing confusion between similar drug names. The "Cytotoxic and Non-cytotoxic Hazardous Drugs" list continues to be revised as new drugs, products, and information become available.

\section{Develop Procedures}

A literature search was performed, CSHP and ASHP guidelines for handling hazardous drugs and the NIOSH resource materials and website were reviewed, and other hospitals were surveyed for pertinent policies and procedures. . $-6,8-12^{-12}$ The applicable standards for "Medication Management" of Accreditation Canada were considered throughout the project. ${ }^{13}$

The 2007 WRHA policy for cytotoxic drugs outlined requirements for personal protective equipment, preparation techniques, dispensing and transport procedures, drug administration, and waste management of parenteral cytotoxic drugs. ${ }^{4}$ Information in this policy was used to develop procedures specific to the WRHA Pharmacy Program to ensure practice consistency across all facilities. The procedures were extended 
Table 2. Excerpt from List of Cytotoxic and Non-cytotoxic Hazardous Drugs*

Cytotoxic Drugs

altretamine
amsacrine
arsenic
asparaginase
azaCITIDine
azaTHIOprine
bleomycin
bortezomib
busulfan
capecitabine
CARBOplatin
carmustine
chlorambucil
CISplatin
cladribine
cyclophosphamide

IDArubicin
ifosfamide
irinotecan
lenalidomide
lomustine
mechlorethamine
melphalan
mercaptopurine
methotrexate
mitoMYcin
mitoXANtrone
nelarabine
oxaliplatin
PACLitaxel
pegasparaginase
PEMEtrexed
pentostatin

Non-cytotoxic Hazardous Drugs

$\begin{array}{ll}\text { acitretin } & \text { megestrol } \\ \text { aldesleukin } & \text { methacholine } \\ \text { alitretinoin } & \text { methylTESTOSTERone } \\ \text { anastrazole } & \text { mifepristone } \\ \text { ambrisentan } & \text { misoprostol } \\ \text { bacillus Calmette-Guerin } & \text { mitotane } \\ \text { (bladder instillation only) } & \text { mycophenolate mofetil } \\ \text { bexarotene } & \text { nafarelin } \\ \text { bicalutamide } & \text { nilutamide } \\ \text { bosentan } & \text { oxandrolone } \\ \text { buserelin } & \text { pentamidine (aerosol only) } \\ \text { cetrorelix } & \text { podofilox } \\ \text { choriogonadotropin alfa } & \text { podophyllum resin } \\ \text { cidofovir } & \text { raloxifene } \\ \text { clomiPHENE } & \text { ribavirin } \\ \text { colchicine } & \text { sirolimus } \\ \text { cycloSPORINE } & \text { tacrolimus }\end{array}$

*This is a partial list, presented for illustrative purposes only. The complete list is revised as new drugs are marketed or become available for use in clinical trials.

to include handling of all dosage forms of cytotoxic drugs. Procedures for the handling of non-cytotoxic hazardous drugs were also based on information presented in the policy, modified to ensure safety and practicality. Personal protective equipment currently available in hospital inventories was recommended.

It was recognized that better alternatives were required for the safe preparation and administration of cytotoxic and non-cytotoxic hazardous drugs at the point of care. Modifying dosage forms to facilitate drug administration was a common nursing practice, and environmental contamination caused by particles generated while manipulating dosage forms in patient care areas (e.g., crushing tablets, opening capsules) was recognized as a safety risk for staff and other patients. ${ }^{14,15}$ Therefore, from the list of cytotoxic and non-cytotoxic hazardous drugs, orally administered drugs were identified, and information on the availability of commercial and extemporaneously compounded liquid preparations, as well as "dissolve-and-dose" information, was compiled. From this, an "Enteral Compromised Dosage Forms" table was developed (not shown). The dissolve-and-dose technique is a "closed-system" method of converting a tablet to a solution or suspension just before administration. ${ }^{16,17}$ Where commercial or extemporaneously compounded liquid preparations were not available, the dissolve-and-dose technique was attempted with selected tablet formulations to confirm dispersion of the tablet in water in less than 5 min (WRHA summer student project, unpublished data, 2007). Because capsules were not amenable to the dissolve-and-dose technique, a procedure was created whereby pharmacy staff open capsules in a dedicated hazardous compounding area of the pharmacy, place the capsule contents in an ointment jar, and seal the container with a unit-dose dispensing cap. Before administration, the nurse adds water to the contents in the ointment jar and withdraws the contents into an oral syringe.

\section{Develop Tools for Front-line Staff}

Procedures for the safe handling of both categories of drugs were summarized in the "Pharmacy Safe Handling of Drugs" chart (see Table 3 for an excerpt from this chart). Details about the personal protective equipment required and other procedures for the handling of parenteral cytotoxic drugs were taken from the 2007 WRHA cytotoxic drugs policy. ${ }^{4}$ Detailed information about personal protective equipment required and other procedures for the handling of other dosage forms of cytotoxic drugs and non-cytotoxic hazardous drugs were developed. All information, including the "Cytotoxic and Non-cytotoxic Hazardous Drugs" list, the "Pharmacy Safe Handling of Drugs" chart, the 2007 WRHA cytotoxic drugs policy, and procedures for non-cytotoxic hazardous drugs, was posted on the WRHA intranet and compiled into a resource manual for ready access by all staff in the WRHA Pharmacy Program.

Three auxiliary labels were selected for use by WRHA Pharmacy Program staff when dispensing designated products. All dosage forms of cytotoxic drugs were labelled with the CSAapproved label for cytotoxic drugs. Labels stating "WEAR GLOVES" and "WEAR GLOVES; DO NOT CRUSH" were used to identify non-cytotoxic hazardous drugs. The labels provided information to nurses about safe handling precautions and alerted them to the availability of additional information 
Table 3. Excerpt from Pharmacy Safe Handling of Drugs Chart*†

\begin{tabular}{|c|c|c|c|c|c|c|}
\hline \multirow[b]{2}{*}{ Precautions } & \multicolumn{3}{|c|}{ Cytotoxic Drugs } & \multicolumn{3}{|c|}{ Non-cytotoxic Hazardous Drugs } \\
\hline & Injectable & $\begin{array}{c}\text { Oral Intact } \\
\text { Dosage Form }\end{array}$ & $\begin{array}{l}\text { Compromised } \\
\text { Dosage Form }\end{array}$ & Injectable & $\begin{array}{c}\text { Oral Intact } \\
\text { Dosage Form }\end{array}$ & $\begin{array}{c}\text { Compromised } \\
\text { Dosage Form }\end{array}$ \\
\hline \multicolumn{7}{|l|}{ Receiving } \\
\hline $\begin{array}{l}\text { Protective wear for } \\
\text { receiving intact stock }\end{array}$ & Exam gloves & Exam gloves & Exam gloves & $\begin{array}{l}\text { No special } \\
\text { requirements }\end{array}$ & $\begin{array}{l}\text { No special } \\
\text { requirements }\end{array}$ & Exam gloves \\
\hline $\begin{array}{l}\text { Protective wear for } \\
\text { receiving damaged stock }\end{array}$ & $\begin{array}{l}\text { Chemo gloves, } \\
\text { mask, gown }\end{array}$ & $\begin{array}{l}\text { Chemo gloves, } \\
\text { mask, gown }\end{array}$ & $\begin{array}{l}\text { Chemo gloves, } \\
\text { mask, gown }\end{array}$ & $\begin{array}{l}\text { Exam gloves, } \\
\text { mask, gown }\end{array}$ & $\begin{array}{l}\text { Exam gloves, } \\
\text { mask, gown }\end{array}$ & $\begin{array}{l}\text { Exam gloves, } \\
\text { mask, gown }\end{array}$ \\
\hline \multicolumn{7}{|l|}{ Preparation and transport } \\
\hline Prepared by & Pharmacy only & Pharmacy only & Pharmacy only & $\begin{array}{l}\text { Nurse or } \\
\text { pharmacy }\end{array}$ & Pharmacy & $\begin{array}{l}\text { Pharmacy } \\
\text { (except } \\
\text { "dissolve-and- } \\
\text { dose" }^{\text {) }}\end{array}$ \\
\hline Preparation area & $\begin{array}{c}\text { Class II safety } \\
\text { cabinet or } \\
\text { alternate closed } \\
\text { system } \\
\end{array}$ & $\begin{array}{c}\text { Dedicated } \\
\text { hazardous } \\
\text { compounding } \\
\text { area } \\
\end{array}$ & $\begin{array}{c}\text { Dedicated } \\
\text { hazardous } \\
\text { compounding } \\
\text { area } \\
\end{array}$ & $\begin{array}{l}\text { Ward or } \\
\text { pharmacy }\end{array}$ & $\begin{array}{c}\text { Dedicated } \\
\text { hazardous } \\
\text { compounding } \\
\text { area } \\
\end{array}$ & $\begin{array}{c}\text { Dedicated } \\
\text { hazardous } \\
\text { compounding } \\
\text { area } \\
\end{array}$ \\
\hline \multicolumn{7}{|l|}{ Protective wear } \\
\hline Staff preparing area & $\begin{array}{c}\text { Chemo gloves, } \\
\text { footwear }\end{array}$ & None & None & None & None & None \\
\hline $\begin{array}{l}\text { Staff preparing drug } \\
\text { doses }\end{array}$ & $\begin{array}{l}\text { Double sterile } \\
\text { chemo gloves, } \\
\text { mask, chemo } \\
\text { gown, footwear }\end{array}$ & Chemo gloves & $\begin{array}{c}\text { Double chemo } \\
\text { gloves, mask, } \\
\text { gown }\end{array}$ & Sterile gloves & Exam gloves & $\begin{array}{c}\text { Chemo gloves, } \\
\text { mask, gown }\end{array}$ \\
\hline Packaging requirements & $\begin{array}{l}\text { Each dose } \\
\text { packaged } \\
\text { separately }\end{array}$ & Unit-dose & Unit-dose & $\begin{array}{l}\text { No special } \\
\text { requirements }\end{array}$ & $\begin{array}{l}\text { Solid: unit-dose } \\
\text { Liquid: unit-dose } \\
\text { or multi-dose }\end{array}$ & $\begin{array}{l}\text { Solid: unit-dose } \\
\text { Liquid: unit-dose } \\
\text { or multi-dose }\end{array}$ \\
\hline Labelling requirements & $\begin{array}{l}\text { CSA-approved } \\
\text { cytotoxic label }\end{array}$ & $\begin{array}{l}\text { CSA-approved } \\
\text { cytotoxic label }\end{array}$ & $\begin{array}{l}\text { CSA-approved } \\
\text { cytotoxic label }\end{array}$ & $\begin{array}{l}\text { WEAR } \\
\text { GLOVES }\end{array}$ & $\begin{array}{l}\text { WEAR GLOVES, } \\
\text { DO NOT CRUSH }\end{array}$ & $\begin{array}{l}\text { WEAR GLOVES, } \\
\text { DO NOT CRUSH }\end{array}$ \\
\hline Packaging for transport & $\begin{array}{l}\text { Sealed container } \\
\text { (e.g. ziplock bag) }\end{array}$ & $\begin{array}{l}\text { Sealed container } \\
\text { (e.g. ziplock bag) }\end{array}$ & $\begin{array}{l}\text { Sealed container } \\
\text { (e.g. ziplock bag) }\end{array}$ & $\begin{array}{c}\text { No special } \\
\text { requirements }\end{array}$ & $\begin{array}{c}\text { No special } \\
\text { requirements }\end{array}$ & $\begin{array}{l}\text { Sealed container } \\
\text { (e.g. ziplock bag) }\end{array}$ \\
\hline Protective wear for clean-up & $\begin{array}{l}\text { Double chemo } \\
\text { gloves, N95 mask, } \\
\text { chemo gown, } \\
\text { footwear }\end{array}$ & Chemo gloves & $\begin{array}{l}\text { Chemo gloves } \\
\text { mask, } \\
\text { chemo gown }\end{array}$ & Exam gloves & Exam gloves & $\begin{array}{c}\text { Chemo gloves, } \\
\text { mask, gown }\end{array}$ \\
\hline
\end{tabular}

\begin{tabular}{lccccc}
\hline $\begin{array}{l}\text { Administration and disposal } \\
\text { Nursing administration }\end{array}$ & & Refer to site-specific policies & & \multicolumn{2}{c}{ Refer to site-specific policies } \\
\hline Handling precautions & Yes & Yes & Yes & WEAR GLOVES & WEAR GLOVES \\
\hline Drug waste management & Yes & Yes & Yes & None & None \\
\hline Human waste management & Yes & Yes & Yes & None & None \\
\hline $\begin{array}{l}\text { Spill management } \\
\text { Yes }\end{array}$ & Yes & Yes & $\begin{array}{c}\text { Chemo gloves, } \\
\text { mask }\end{array}$ & $\begin{array}{c}\text { Chemo gloves, } \\
\text { mask }\end{array}$ & $\begin{array}{c}\text { Chemo gloves, } \\
\text { mask }\end{array}$ \\
\hline
\end{tabular}

CSA = Canadian Standards Association.

*This is an excerpt from the original chart and is provided for illustrative purposes only.

tDisclaimer: The Winnipeg Regional Health Authority (WRHA) Pharmacy Program "Pharmacy Safe Handling of Drugs" chart was developed as a resource for pharmacy personnel to provide direction in the safe handling of cytotoxic and non-cytotoxic hazardous drugs as defined in the "Cytotoxic and Non-cytotoxic Hazardous Drugs" list. The information presented in this chart is intended for the use of pharmacy staff of the WRHA and CancerCare Manitoba only. The authors have made every effort to ensure that the information presented was accurate at the time of publication. As new research and experience broadens our knowledge, changes in handling requirements as well as the drug list will be required. The authors, reviewers, and publishers are not responsible for errors, omissions, inconsistencies, or continued completeness of the information contained in the chart or drug list. The information in this chart and the drug list should not be used in place of the skill and professional judgment required when determining appropriate handling of these drugs. Information on the drug list will be reviewed and updated periodically; however, ongoing accuracy at particular points in time cannot be assured. 
such as specific policies and procedures. Application of labels with the instruction "DO NOT CRUSH" to particular dosage forms delivered to patient care areas also helped to ensure that all compromised dosage forms would be prepared in a controlled environment within the pharmacy department to the greatest extent possible. Information about the auxiliary labels was included in the "Pharmacy Safe Handling of Drugs" chart.

\section{Develop Implementation Plan and Training Program}

The Safe Handling of Hazardous Drugs Program was implemented in 8 pharmacy departments within the WRHA. To facilitate implementation, educational material about the program was developed for all existing staff in the WRHA Pharmacy Program and for orientation of new staff. A refresher quiz was developed for annual completion by all pharmacy staff. Education focused on providing consistent information about the safe handling of hazardous drugs and instruction regarding use of the resource tools. Tools such as an implementation checklist, self-learning package, and inservice slide presentation were developed by the Practice Development Team of the WRHA Pharmacy Program, to aid pharmacy managers in implementing the program at their facilities. The learning objectives for the educational materials included listing the potential hazards and conditions for exposure to cytotoxic and other hazardous agents, identifying and differentiating between cytotoxic and non-cytotoxic hazardous drugs, using the "Pharmacy Safe Handling of Drugs" chart to identify precautions to be taken when handling both categories of hazardous drugs, and identifying procedures to use when cleaning up a hazardous drug spill. Before delivery of the educational materials to pharmacy staff, 8 pharmacists and pharmacy technicians participated in a field test of the materials, the self-learning package, and the inservice presentation. The field test included a self-assessment evaluation, a post-education survey, and focus group discussion about the resource material and education process. The resource materials and education package were revised on the basis of feedback from the fieldtesting participants and an educator.

Guided by the implementation checklist, pharmacy managers assessed available space and workload to determine the best plan for implementing the safe drug-handling procedures. The inservice presentation was customized for each facility. Implementation started with the largest facility and then progressed through the other facilities. Inservice sessions were presented by members of the WRHA Pharmacy Program Practice Development Team or a site-specific pharmacy educator. All staff members were required to attend an inservice session, and attendance was recorded for quality assurance purposes.
The Safe Handling of Hazardous Drugs Program has been implemented at all 8 facilities of the WRHA Pharmacy Program. More than 300 staff members attended the initial education sessions. Resource tools and educational materials have been in use at all facilities since spring 2009. As of April 2011, about $80 \%$ of pharmacy staff across the region had completed the annual refresher quiz.

\section{DISCUSSION}

There were many challenges to developing a program that would protect staff from hazardous drugs and that would be both practical and adaptable to a variety of practice settings. One of the earliest challenges was developing standard terms and definitions that would be recognized and used across the region. Although the NIOSH recommendations for full cytotoxic safety precautions for all hazardous drugs offer maximal protection to staff, they are not practical for implementation in diverse health care organizations. We modified the recommendations so that staff could adopt practices that would ensure quality and timely patient care in a safe handling environment.

It was also difficult to find published recommendations that were applicable to a variety of practice settings and to all dosage forms of hazardous drugs. Often, we found information that was specific to only antineoplastic agents or to parenteral dosage forms. We sometimes had to extrapolate the information to make it applicable to hazardous drugs that were not antineoplastics or to oral or topical dosage forms. The hazardous drug list and procedures are continually being revised to reflect new and more definitive information as it becomes available. Future efforts will focus on making this safe-handling information available to all WRHA employees, especially nursing staff, in all of our care facilities and in the community.

\section{CONCLUSIONS}

The Safe Handling of Hazardous Drugs Program was developed and implemented within the WRHA Pharmacy Program. This program provides complete, easily accessible information to pharmacy personnel across all facilities of the WRHA about safe handling of hazardous and potentially hazardous drugs. A list of cytotoxic and non-cytotoxic hazardous drugs, a chart for safe handling of drugs in the pharmacy, and a pharmacy resource manual with information about the safe and preferred methods for altering dosage forms to accommodate patient needs were created. An extensive regional education program and an implementation process were also developed. The implementation process recognized the need for variation among individual facilities while providing a consistent message about the safe handling of hazardous drugs. 


\section{References}

1. Health Canada. Workplace hazardous materials information system-official national site. Ottawa (ON): Health Canada; [modified 2010 Jun 10; cited 2011 Oct 28]. Available from: www.hc-sc.gc.ca/ewh-semt/occup-travail/ whmis-simdut/index-eng.php

2. Preventing occupational exposure to antineoplastic and other hazardous drugs in health care settings. Atlanta (GA): US Centers for Disease Contro and Prevention, National Institute for Occupational Safety and Health; 2004 Sep [cited 2011 Jun 6]. Available from: www.cdc.gov/niosh/ docs/2004-165c

3. Hazardous pharmaceuticals (including cytotoxic drugs): guidelines for handling and disposal. Ottawa (ON): Canadian Society of Hospital Pharmacists; 1997 [cited 2011 Jul 12]. Available from: www.cshp.ca/dms/dmsView/1_G_Hazardous_Pharmaceuticals_1997.pdf

4. Regional policy 110.160.010: Cytotoxic agents, safe handling of Winnipeg (MB): Winnipeg Regional Health Authority; 2007 Oct.

5. ASHP guidelines on handling hazardous drugs. Bethesda (MD): American Society of Health-System Pharmacists; 2006 [cited 2011 Jun 3]. Available from: www.ashp.org/DocLibrary/BestPractices/PrepGdlHazDrugs.aspx

6. International Society of Oncology Pharmacy Practitioners Standards Committee. ISOPP standard of practice: safe handling of cytotoxics. J Oncol Pharm Pract 2007 [cited 2011 Jun 14];13(3 Suppl):1-81. Available from: http://opp.sagepub.com/content/13/3_suppl.toc

7. FDA and ISMP lists of look-alike drug names with recommended tall man letters. Horsham (PA): Institute for Safe Medication Practices; 2011 [cited 2012 Feb 9]. Available from: www.ismp.org/Tools/tallmanletters.pdf

8. Pharmacy procedures for sterile product preparation: Video 3: Antineoplastic agents. Ottawa (ON): Canadian Society of Hospital Pharmacists; 2003.

9. Standards of practice for oncology pharmacy in Canada. Version 2. North Vancouver (BC): Canadian Association of Pharmacy in Oncology; 2009 Nov.

10. Polovich M. Safe handling of hazardous drugs. Pittsburgh (PA): Oncology Nursing Society; 2003.

11. Working Committee on the Safe Handling of Hazardous Drugs. Prevention guide: safe handling of hazardous drugs. Technical Guide CG-002. Montréal (QC): Association paritaire pour la santé et la sécurité du travail du secteur affaires sociales; 2008 [cited 2011 Jun 17]. Available from: www.irsst.qc.ca/en/-irsst-publication-prevention-guide-safe-handling-ofhazardous-drugs-cg-002.html

12. Special handling requirements for oral cytotoxics and cytotoxic immunosuppressant medicines. London (UK): NHS Foundation Trust, Great Ormond Street Hospital for Children; 2010 May [cited 2011 Jun 16]. Available from: www.gosh.nhs.uk/gosh_families/information_sheets/ medicines_chemotherapy_handling/medicines_chemotherapy_handling_f amilies.html

13. Managing medications standards. Ottawa $(\mathrm{ON})$ : Accreditation Canada; 2011 [cited 2011 Jun 22]. Available from: www.accreditation.ca (payment required to access content).
14. Timpe EM, Motl SE, Hogan ML. Environmental exposure of health care workers to category D and X medications. Am J Health Syst Pharm 2004;61(15):1556-1557,1560-1561.

15. Harrison BR, Schultz CD. Determination of tablet trituration dust in work zone air. J Oncol Pharm Pract 2000;6(1):23.

16. Beales J, Honcharik N. Administration of medications via a nasogastric tube [letter]. Can J Hosp Pharm 1991;44(3):107-108.

17. Martin TP, Hayes P, Collins DM. Tablet dispersion as an alternative to formulation of oral liquid dosage forms. Aust I Hosp Pharm 1993; 23(6):378-386

Barbara Sproll, BSc(Pharm), is Regional Medication Safety Pharmacist for the Winnipeg Regional Health Authority, Winnipeg, Manitoba.

Heather Milan, BSc(Pharm), was Regional Pharmacy Manager (now retired) with the Winnipeg Regional Health Authority, Winnipeg, Manitoba.

Cenzina Caligiuri, BSc(Pharm), is Regional Pharmacy Manager with the Winnipeg Regional Health Authority, Winnipeg, Manitoba.

Sheri Dyck, BSc(Pharm), ACPR, is Coordinator, Pharmacy Operations, St Boniface Hospital, Winnipeg, Manitoba.

Brenda Rosenthal, BSc(Pharm), is a WRHA Drug Information Pharmacist with the Department of Pharmaceutical Services, Health Sciences Centre Hospital, Winnipeg, Manitoba.

Colette B Raymond, PharmD, MSC, ACPR, is Staff Development/ Practice Evaluation Pharmacist for the Winnipeg Regional Health Authority, Winnipeg, Manitoba.

\section{Address correspondence to:}

Barbara Sproll

Winnipeg Regional Health Authority

clo Deer Lodge Centre

North Pavilion, 2nd Floor

2109 Portage Avenue

Winnipeg MB R3J OL3

e-mail: bsproll@wrha.mb.ca

\section{Acknowledgements}

The contributions of Anita Richard, Susan Mestdagh, and Clayton Hayes and of all the members, past and present, of the Winnipeg Regional Health Authority Hazardous Drugs Task Force, are gratefully acknowledged.

\begin{tabular}{lll}
\multicolumn{3}{c}{ Advertisers } \\
\hline & Ad Page & \\
\hline Fresenius Kabi / Voluven and Volulyte & IFC & 238,239 \\
\hline Hospira / Corporate & 177 & - \\
\hline Hospira / Docetaxel & 174 & - \\
\hline Otsuka / Samsca & 172,173 & 240,241 \\
\hline Pfizer / Fragmin & IBC & $242-245$ \\
\hline Pfizer / Injectables & 170 & - \\
\hline Pharmaceutical Partners of Canada / Corporate & OBC & - \\
\hline
\end{tabular}

